\title{
Science Instructional Media in the Form of Magic Game on Concept of Solid in Early Class of Primary School
}

\author{
Irvin Novita Arifin \\ State University Of Gprpntalo, Gorontalo, Indonesia \\ e-mail: irvin.novita@gmail.com
}

\begin{abstract}
One of learning with approach to play through learning is science learning. The science learning given in this way is one of the appropriate alternatives in introducing the concept of science to children because basically science learning can improve cognitive, affective, and psychomotor development, and foster thinking ability of children. The introduction of the concept of science to early class children cannot be separated from the role of the teachers as educators, because teacher has the important role. The science material presented is chosen in such a way that it can be presented more attractively. The learning process is done through interesting activities, arousing curiosity, motivating children to think critically and discovering new things, therefore the instructional media is presented with an interesting and creative activity that is using the magic game technique on the basis of that it is needed to do in-depth study of science instructional media in the form of a magic game on the concept of solid effect in the early classroom school.
\end{abstract}

Keywords: $\quad$ Media Learning, Magic Games

\section{INTRODUCTION}

In preparing the generation of qualified human required effective media and has been tested able to deliver it, one of the affective media is education which is one of the important supports in preparing qualified human resources, helping to develop one's potential to become a qualified human in various fields. Therefore, it is clear that education can improve personal quality, develop the potential of children and make them become qualified selfsufficient people.

The information regarding the potential quality of the children has been widely discussed both the mass media and electronic media. Child is a unique individual that must be maintained and cared for, because that is the God's creature. The role of parents and environment play an important role in developing the potential of children. In consequence, nowadays a child must be really considered related to education among in family environment, school and society. Parents and government are required to provide educational facilities and infrastructure for children in the context of learning programs.

In accordance to article 28 of the National Education System no. 20/2003 paragraph 1, which includes early childhood, is children who fall within the age range 0-6 years. Meanwhile, according to study of early childhood education and organizing in several countries, PAUD is implemented since the age of $0-8$ years. Another opinion mentions that it is groups of children who are in the process of growth and development and unique. Such as the pattern of growth and development (coordination of fine and rough motor), intelligence (thought power, creativity, emotional intelligence, and spiritual intelligence), emotional social (attitude and behavior as well as religion), language, specific communication according to the child's growth and development level.

As Vigotsky (1979) states, a child learns through playing with others, creating and improving his or her zone of proximal development, because playing often involves more complex activities than those the child experiences in daily life. In correspondence with this idea are Bruner's (1986) findings that children normally use more complex grammatical structures while playing than they do in real life situations. As such, playing offers the cognitive support needed to develop higher order mental processes. Playing initiates the symbolic use of objects and is therefore considered the first form of symbolization (Piaget, 1951). Thus, playing 
constitutes the first step towards abstract thinking (Vigotsky, 1976).

The primary school age of the early grade is an important and fundamental development stage for subsequent development success. Early childhood cognitive development is still in concrete operation stage. At this stage the child is able to think logically through concrete objects, and that is the beginning of rational thinking. Learning of children activity and the way of thinking at this concrete operational stage in part through real experience, namely from the process of interaction with objects and not with symbols, ideas, or abstractions. Children at this concrete operational stage have not been able to perform the process of abstract thinking as imagined. Learning plays through learning is one of the right alternatives in introducing the concept of science to children because basically science learning can improve the development of cognition, affection and psychomotor as well as foster thinking ability of children.

The introduction of the concept of science to early class children cannot be separated from the role of teachers as educators. This is because the teacher is a determinant of the success of learning children and who develop the potential of children in the learning process. Before the learning process, teachers should prepare a lesson plan so that learning activities can be directed and achieve the expected learning objectives.

Teachers are expected to implement science learning for children should placing with real activity with the various objects being studied which is the main thing that needs to be developed on various occasions in providing science learning the child should be in direct contact with the object to be studied.

In the observation in the introduction of the concept of science that has been done, the guidance provided has not fully obtained the child optimally. It is seen that the learning given still does not have the appropriate material with the learning. For example in the concept of science materials about classifying the properties of objects and changes in the form of objects. Teachers only provide the concept that already exists in the book without realizing it. In fact the concept is not far from the daily life of the child.

The science material presented is chosen in such a way that it can be presented more attractively. The learning process is done through interesting activities, generate curiosity, and motivate children to think critically as well as discovering new things. Therefore the instructional media is presented with an interesting and creative play activity that is using the magic game technique. Based on the above statement, it is necessary to conduct a research on the situation in the field. The researcher is interested in doing research on science learning with the title "development of science instructional media in the form of magic game on solid".

Research Beyond Nintendo: design and assessment of educational video games for first and second grade students. A. School of Psychology, Pontificia Universidad Catolica de Chile, Santiago, Chile. B School of Engineering, Pontificia Universidad Cato lica de Chile, Santiago, Chile. Regarding the effects of video games over initial learning, significant. differences were found between the EG and IC groups in relation to the EC group in Math, Reading Comprehension and Spelling. With regard to the effects on motivation, there are three main indicators that indicate the positive effects of the experimental tool. First, the choice of activities during class and recess periods: during both, students preferred playing the video game over other activities, although the strength of the relationship was stronger within the classroom environment than within the recess period. Second, the positive qualitative assessment from teachers and their use of this tool to motivated the students' attendance and punctuality. Third, the reports indicating that the stu-dents increased their concentration and attention while playing with the experimental video game, compared to classroom observations without its use.

\section{METHODS}

The method used in this research is a development research that aims to produce a product that is a science learning media in the form of "magic game" This research refers to the opinion of Borg \& Gall (1979), that in research and development (Research and devolopment) stages are A cycle that includes a review of the findings of field research relating to the product of a magic game produced and developed, so that the results and the resulting product are not limited to materials such as books and so on but may also take the form of a procedure or process.

\section{DISCUSSION}

\subsection{The Nature of Instructional Media}

Learning process is a communication. In the communication process involves three 
components namely the messaging component (teacher), the recipient component (child), and the components of the message itself which is usually a learning material. Sometimes in the learning process there is a failure to communicate. To avoid all that, then teachers can develop learning strategies by utilizing various media and learning resources.

Media is a tool that conveys or delivers teaching messages (Azhar Arsyad, 2010: 3) .Gagne) mentioned that the media is the various types of components in students environment that can motivate students to learn. According to Briggs (Arsyad, 2002: 6) media are all physical tools that can present the message and stimulate the child to learn.

In the world of education, media is used to convey learning materials to be easily accepted by children, because the abstract objects can be concrete by using the media. In other words teachers, textbooks, and school environments are media.

From some opinions above can be concluded that the media is not just a visual tool that is only heard and seen however the media is a tool that can convey a message or information that can stimulate the minds of children to be motivated in the learning process and the learning process becomes effective and optimal.

All physical tools that can present the message and stimulate the child to learn is the game are a common form of playing. All games have properties, rules and procedures that must be mastered in order to become a "player'. The understanding of the underlying concepts of games plays an important organizing role in cognition, similar to that of a story schema (Schank, 1990), in that it requires a mental framewor kwhich includes goals, conditions, players, and resolutions. Since playing games is a natural activity for children it is considered an excellent example of situated or " anchored", learning through authentic situations (Choi \& Hannafin, 1995; Herrington \& Oliver, 1999; Rogoff, 1993). Playing changes as children grow up, following the course of cognitive development. The games played, their rules and meanings change as a child grows up. Once a child reaches school age, she or he is able to understand and follow the rules involved in structured games. Even though such rules are also present in learning situations found in a school setting, teachers usually view them as different and tend to separate school from play (Rieber, 1996).

\subsection{The Benefits of Instructional Media}

The use of instructional media will greatly assist in the effectiveness of the learning process. In addition to motivate children's interests, media can also help children to improve their understanding by presenting data interestingly. There are several benefits of instructional media according to (Arsyad 2011: 24).

1) Teaching will attract more children so that will be able to cultivate learning motivation

2) The teaching materials will be more clear the meaning

3) Learning methods will be more varied, so that children do not get bored and teachers do not run out of energy

4) The child can be active in the class

In line with what was stated by Ahmad Rivai (2002: 3 ) the benefits of instructional media as follows:

1) Teaching will attract more children so that can motivate them to learn

2) Teaching materials will be more clearly meaning so that it can be more understood by the children and enable children to master the aim of learning better.

3) Teaching methods will be more varied, not merely communicate verbally through the words by the teacher. So that the child is not bored and the teacher does not run out of energy, moreover teacher teach for every hour of study

4) The child is more doing learning activities, because not only listening to the teacher's description, but also other activities such as observing, performing, demonstrating, and others.

Magic game become one of the interesting learning media in learning application, the magic game in science learning does not involve magical or mystical things on the other hand this magic game is designed to make it easier for elementary school children to understand the concept of solid science.

Solid or solid substances are substances that can maintain their shape, the force between molecules is very strong to maintain the firmness of the substance. But if the substance is influenced by energy then the material can change its form.

And this change is called a change of physics. In this physical change which produces no new substance, i.e. the change of place, the shape of the size, and the shape of the thing.

In science learning will be explained about the concept of science that changes solids into liquid. For example in everyday life i.e. ice cubes 
that will melt if being exposed to the sun. This concept will be explained to the children. Not only explain it with theory but also it is presented as interesting as possible so that children are not saturated and bored, and children do not feel that learning science is difficult to learn and understand. Therefore more details will be presented by examples of magic games science learning on the concept of solids as follows:

$\begin{array}{ll}\text { Title } & : \text { change of solid } \\ \text { Objective } & : \text { to know changes in } \\ \text { solids } & : \\ \text { Tools and materials } & : \\ \text { Ice cubes } & \\ \text { Glass } & \\ \text { Candle } & \end{array}$

How it works

Light a candle fire

insert ice into the glass

Place a glass that contains ice cubes on a candle fire

Observe what happens.

Observation : ice cubes in a glass melt Conclusion $\quad:$ in this experiment ice cubes can melt due to pressure from heat energy so that when the ice cubes in the heat it will melt into water.

From the research result, it is found that science learning which is packed with magic game is seen when the teacher explain about the various solids, the curiosity of the child increases to know what is meant by solid and its change. Children are very enthusiastic in following this game so that the interaction between children and teachers, the existence of this feedback indicates that the child responds, catch what has been explained by the teacher. This learning of science is more focused on the concepts of solid-state change that are packed with interesting so that children can accept and understand what is conveyed by the teacher.

From the experimental implementation of the concept of science in solids done with the magic show that children are more active and more understanding of the concept of science given, children more easily understand the concept of solids that exist around.

\subsection{Early Classroom Science Learning \\ From the point of language, Science (in} English), derived from the Latin, i.e. from word scientia which means knowledge. Amien (in Nugraha, 2008: 3), defines science as the field of natural science, with the scope of substance and energy, both living and nonliving, more about natural sciences such as physics, chemistry and biology.

James Conant defines science as a sequence of concepts and conceptual schemes related to each other, growing as a result of a series of experiments and close observations can be observed and tested further. While Fisher (2008: 4) defines science as a collection of knowledge obtained by using methods based on observation with great care.

From the above description can be concluded that science is a collection of knowledge that is universal that contains various human values and can be developed and owned by every individual.

\section{CONCLUSIONS AND SUGGESTIONS}

\subsection{Conclusion}

From the discussion that has been described previously, it can be concluded that the science instructional media in the form of games can facilitate teachers in conveying the concept of science concerning solid, science learning is packed in the form of a magic game media more motivate and attract the attention of children, the activity of a magic game in a solid-change experiment conducted can actively engage the children so that the children perform on their own and see the results of their experiments, children more easily understand the concept of solids change for example in the heated candle will melt then on the second activity on the ice cubes that are also heated will melt, and the sugar melts when heated.

The experiments performed by the children among observing, explaining, identifying, communicating by involving the children doing themselves, the child will more easily understand about the concept of solid science.

\subsection{Suggestions}

Teachers should make an interesting instructional media of science in learning so that children can be more familiar with the concept of science on the solids change. And schools, should be able to apply the science instructional media in the form of a magic game so that children better understand the concept of science. 


\section{REFERENCES}

[1] Arsyad.2011.media pembelajaran.Jakarta.Rajawali Pres

[2] Nugraha, Ali.2008.pengembangan pembelajaran sains pada anak usia dini. Bandung: CV. Afabeta.

[3] Rieber, L (1996). Seriously considering play

[4] Rivai, A.2007.media pengajaran.Bandung: Sinar Baru Algensindo

[5] Sanjaya, Wina 2006.strategi pembelajaranberorentasistandar proses pendidikan.jakarta:Kencana Prenada Media.

[6] Schank, R.C (1990).Tell me a story: a new look at real an artificial memory. New York: Scribner

[7] Yulianti Dwi. 2010.bermain sambil belajar sains di taman kanak-kanak. Jakarta:PT.Indeks

[8] Vigotsky, L. (1979). El desarrollo de los procesos psicologicos superiors. Barcelona:Critica. 